\title{
Numerical Simulation of the Evaporative Air Cooler with a Capillary-Porous Structure Arseniev V. M., Shulumei A. V.
}

${ }^{1}$ Sumy State University, 2 Rymskogo-Korsakova St., 40007 Sumy, Ukraine

\section{Article info:}

Paper received:

The final version of the paper received:

Paper accepted online:
June 22, 2018

October 5, 2018

October 10, 2018
*Corresponding Author's Address:

anton.shulumey@gmail.com

\begin{abstract}
Application of evaporative air cooling in various technologies allows reducing energy costs for improving environmental performance. Considering the promise of using air coolers with a capillary-porous structure, a mathematical model of the working process for such devices of contact heat of mass transfer was developed. The model takes into account the completeness of the process with temperature efficiency equal to $0.6-0.7$ at constant water temperature at the temperature level of the wet thermometer. The estimation of energy efficiency of the air cooler on the basis of the exergent method of thermodynamic analysis is proposed. As a result, the thermophysical and design model of evaporative cooling of air in air-cooled contact type with capillary-porous structures was developed. The proposed method of cooling air is characterized by the following advantages the lowest water consumption per unit of heat exchange surface compared with other methods (e. g. spray nozzles), as well as zero discharge of drip liquid, which does not require further separation. Finally, the estimation of energy efficiency of the air vent is proposed on the basis of the exergent method of thermodynamic analysis.
\end{abstract}

Keywords: evaporative cooling, capillary-porous structure, thermophysical modelling, exergy efficiency.

\section{Introduction}

Evaporative cooling of water and atmospheric air is one of the first ways to implement artificial cold in the history of human development. Modern problems in lowenergy energy and environment require the search for alternative solutions in the field of climate technology. Evaporative cooling is a non-mechanical way, but its efficiency is significantly limited by climatic conditions. At the same time, interest in the possibilities of evaporative coolers has increased in recent years, due to their low energy consumption and environmental cleanliness [1-3].

Among the technical systems for which evaporative cooling can significantly improve the thermoeconomic efficiency are compressor and gas turbine units. As it is known, when working compressor plants with compression of atmospheric air there is a deviation of the regime parameters from the nominal due to changes in the thermal parameters of the air at the input: pressure, temperature and relative humidity.

The most negative consequences are associated with an increase in the temperature of atmospheric air. For compressors of the volume principle of operation (compressor installations of general purpose, small and medium air separation units), the increase in air temperature in the suction is primarily manifested in the reduction of mass productivity and increase in energy consumption in the intermediate and final cooling. For turbochargers (gas turbine units, compressor stations for mine and chemical production), the power of the drive significantly increases.

In the paper [4] the dependence of the relative reduction of the effective power of the gas turbine unit with increasing temperature of the intake of the cyclic air is shown, experimental for GTU of the mark LM 1600 "General Electric" with Ne, iso $=15 \mathrm{MW}$ and calculated for GTU AL-31ST with Ne, iso = $16 \mathrm{MW}$

According to the graph of the increase in the temperature of air intake from $15{ }^{\circ} \mathrm{C}$ (nominal mode ISO) to $40{ }^{\circ} \mathrm{C}$ reduces the effective power GTU at $18-20 \%$, which corresponds to losses of about $3 \mathrm{MW}$ for the considered installations.

To cool the air at the suction, air coolers of the surface or contact type are used depending on the required depth of cooling or cold water capacity.

The required cold-productivity is provided by the operation of refrigerating machines, mainly heatdischarging waste streams of heat.

Contact air coolers are suitable for technological air conditioning in premises where it is necessary to maintain high relative humidity (spinning, paper production, etc.). From the position of capital and operating costs, contact air coolers have an advantage over surface type devices for cooling cyclic air gas turbine engines.

The main disadvantage of contact air coolers is the increased attribution of droplet moisture to the air flow, 
requiring its separation or ensuring its evaporation in the process of compression of air.

In this regard, air coolers with porous ceramics or capillary-porous structures of composite materials are of particular interest. Evaporative cooling using capillaryporous materials allows the film flow to be eliminated on the contact surfaces of the apparatuses and the dropping of moisture from the heat transfer surface.

\section{Research Methodology}

\subsection{Thermophysical description of the calculation model}

Figure 1 shows simplified schemes for two design variants of air coolers using capillary-porous structural elements, the heat of mass exchange between air and water.

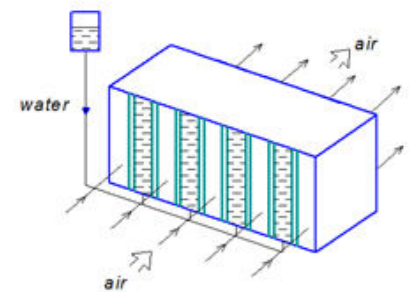

a

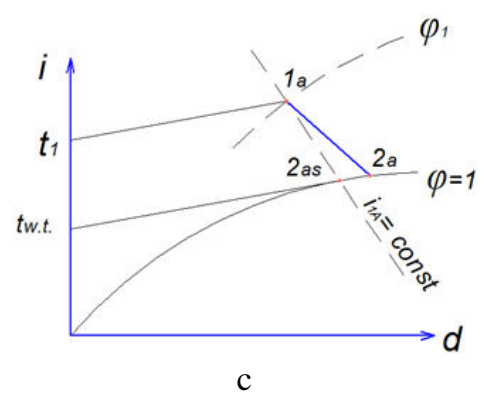

Figure 1 - Evaporative air coolers: a - multi-channel with walls of capillary-porous materials; $b$ - heat exchange unit with

a bundle of pipes from capillary-porous materials; $\mathrm{c}$ - process in " $\mathrm{i}-\mathrm{d}$ " diagram

According to Figure 1 a, porous walls divide flat parallel channels with water and air passage. Water in the channels is replenished as it moves through the capillaries and evaporates into the air at the expense of the reservoir of water in the tank.

A pumping movement of water through the apparatus can also be organized. Filling with water is organized through one row of channels.

According to the scheme in Figure $1 \mathrm{~b}$, the heat exchange unit has a conventional constructive solution for airflow of a beam of non-circular pipes with a corridor or chess arrangement, in which the pipes are characterized by a fine porosity of $2.0-2.5 \mu \mathrm{m}$. Material of pipes: ceramics, plastics, composite materials. Water in pipes is supported either by gravity pressure or by pump circulation.
Taking into account a number of features inherent in the process of evaporative cooling in the capillary-porous structures, the following assumptions were adopted:

- the temperature of the liquid in the channels is constant and is equal to the temperature of the wet thermometer;

- the temperature efficiency of the process is limited by the value $E_{a}=0.6$;

- there is no heating of the main mass of the liquid;

- the contact surface of the media is completely moistened with water by blurring the air flow of the meniscus volume of droplets, which flows from the water of the water;

- there is no attribution of droplet moisture;

- gas-dynamic air resistance neglected;

- in the temperature range the dependence of the partial pressure of the saturated water vapor on the temperature is taken as a linear function;

- the notion of cold productivity becomes incorrect in view of inequalities $i_{2 \mathrm{a}}>i_{1 \mathrm{a}}$, it is more correct to consider the ability to humidify the air, that is, its increase in moisture content.

The conceptual task of the calculation model is to determine the required area of the contact surface of the capillary-porous structure, on which the change of the parameters of the air flow along the line of heat - logistic relation is realized, taking into account the accepted value of the temperature efficiency of the evaporative cooling process.

For the temperature efficiency $E_{a}$ parameters of air flow at the outlet of the air cooler is characterized by the expressions:

$$
t_{2 a}=t_{1 a}-E_{a}\left(t_{1 a}-t_{2 a s}\right)
$$

where $\varphi_{2 . A}=0.98-1.00$, which allows to find the moisture content, $x_{2 \mathrm{a}}$ and enthalpy, $i_{2 \mathrm{a}}$ in the state of $2 \mathrm{a}$ and determine the thermal logic ratio:

$$
\varepsilon_{A C}=\frac{i_{1 a}-i_{2 a}}{x_{1 a}-x_{2 a}}
$$

By breaking the intervals of change in the moisture content in the apparatus, $\left(x_{1 a}-x_{2 a}\right)$, on the elementary regions along the line $\varepsilon_{A C}$ we obtain the possibility of determining the thermal, caloric and thermophysical parameters of air from the state $1 \mathrm{a}$ to $2 \mathrm{a}$ by the equations used in the calculations of air conditioning systems and convective drying of moist materials [7].

The very process of energy interaction between environments is described by the equation of thermal balance:

$$
Q_{\alpha}=Q_{\beta}+Q_{w},
$$

which shows that the convective heat flowing away from the air flow, $Q_{\alpha}$ goes to the evaporation of the moisture from the wetted surface, $Q_{\beta}$ and to the heating of the fluid flow in the middle of the channels or tubes of the apparatus, $Q_{w}$. 

form:

In turn, the component equations are written in the

$$
\begin{gathered}
Q_{\alpha}=\alpha \cdot F_{\alpha} \cdot\left(t_{\alpha}-t_{w}\right) ; \\
Q_{\beta}=r \cdot G_{B w}=r \beta_{p} F_{\beta}\left(p_{w}-p_{a}\right) ; \\
Q_{w}=G_{w} c_{w} \Delta t,
\end{gathered}
$$

where $\alpha$ - coefficient of heat transfer; $F_{\alpha}$ - surface area of heat transfer; $\left(t_{a}-t_{w}\right)$ - air temperature in the core of the stream and water on the surface of evaporation; $r$ - specific heat of vaporization of water at $t_{w}$; $G_{e v}$ - mass flow rate of evaporated water; $\beta_{p}$ - the coefficient of evaporation is determined by the difference of partial pressure of water vapor, $p_{w}-$ at the surface of water and $p_{a}$ - in the core of the stream; $G_{w}$ - mass flow rate of water when it is circulating through channels or pipes; $c_{w}$ - average heat capacity of water in the interval of temperature changes; $\Delta t=t_{2 w}-t_{1 w}$ - water heating in the machine.

The heat flux to the liquid $Q_{w}$ is realized under the condition

$$
G_{w} \cdot c_{w} \cdot \Delta t_{w}=k_{w} \cdot F_{w} \cdot\left(t_{a}-t_{w}\right)
$$

where $k_{w}$ - the coefficient of heat transfer from air to water through the distribution surface, the area of $F_{w}$.

Assuming equality $F_{\alpha}=F_{\beta}=F_{w}$ :

$$
\alpha \cdot\left(t_{a}-t_{w}\right)=r \cdot \beta_{p} \cdot\left(p_{w}-p_{a}\right)+\frac{G_{w}}{F_{w}} \cdot c_{w} \cdot \Delta t_{w}
$$

In the absence of water circulation $\Delta t_{w}=0$ :

$$
\alpha \cdot\left(t_{A}-t_{w}\right)=r \cdot \beta_{p} \cdot\left(p_{w}-p_{A}\right)
$$

To determine the quantities on the interface of the media, we can use the linearized approximation dependence of the partial pressure of the saturated water vapor $p_{s}(t)$ on the temperature as proposed in [11]:

$$
p_{s}(t)=a+b \cdot t
$$

After the appropriate changes:

$$
p_{w}-p_{a}=p_{s}\left(t_{a}\right) \cdot \frac{1-\varphi_{a}}{1+\frac{b}{A}}
$$

where the complex $A=\frac{\alpha}{\beta_{p} \cdot r_{p}(t)}$ - the psychometric coefficient.
For the calculation of the technical characteristics of the air cooler on the capillary-porous structures, the following expressions were obtained:

- consumption of evaporating water per unit of heat exchange surface:

$$
q_{F}=\beta_{p} \cdot p_{s}\left(t_{w}\right) \cdot \frac{1-\varphi_{1 a}}{1+\frac{b}{A}}, \frac{\mathrm{kg}_{\mathrm{H}_{2} \mathrm{O}}}{\mathrm{m}^{2}} ;
$$

- water consumption for evaporation:

$$
G_{e v}=m_{\text {d.a. }} \cdot\left(x_{1 a}-x_{2 a}\right), \quad \frac{k g_{H_{2} O}}{m^{2}}
$$

- area of heat exchange surface:

$$
F_{t o t}=\frac{G_{e v}}{g_{F}}, m^{2}
$$

- relative water consumption:

$$
G_{w}=\frac{G_{a}}{m_{a}}=\frac{x_{1 a}-x_{2 a}}{1+x_{1 a}} ;
$$

where the coefficient of mass return is determined from the expression:

$$
\beta_{p}=\frac{\alpha}{L e \cdot c_{p a} \cdot P_{t o t}}
$$

In this formula, the Lewis criterion $L e$ is considered as the ratio of the molecular diffusion coefficient at $P_{\text {tot }}$ and the air temperature in the boundary layer to the air-cooled coefficient under the same conditions.

\subsection{Energy efficiency of the evaporative cooling process}

For contact type coolers, energy efficiency is considered as the relative value of air temperature differences, which takes into account the non-adiabativity of the energy conversion process. This value is called the temperature efficiency and is written as:

$$
E_{a}=\frac{\left(t_{1 a}-t_{2 a}\right)}{\left(t_{1 a}-t_{2 a s}\right)}
$$

However, the magnitude of the $E_{a}$ takes into account only the lack of recuperation for air cooling, due to the non-indifference of the process and does not take into account the internal irreversibility in the form of gasdynamic resistances along the airway.

Based on the exergent method of thermodynamic analysis by $\mathrm{J}$. Tsatsaronis [8] and used for refrigeration and heat pump technology $[9,10]$, it can be considered the exergic efficiency of power transitions in a contact air cooler. 
Formalized scheme of exergent transformations is presented in Figure 2.

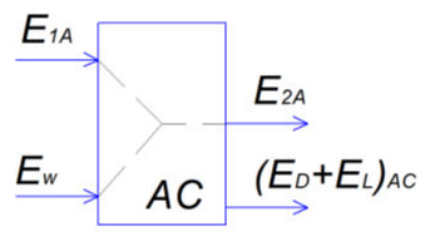

Figure 2 - Design scheme of exergent transformations in an air cooler in capillary-porous structures at $t_{1 w}=t_{w . t}$

On this scheme it is indicated:

$-E_{1 a}, E_{2 a}$ - exergy of the airflow on the input and output of the apparatus;

$-E_{w}-$ exergy of water at the entrance to the capillary canals;

$-\left(E_{D}+E_{L}\right)_{A C}-$ exergy of destruction and loss in the air cooler.

To determine the exurance of the fuel flow, $E_{F}$ and product flow $E_{R}$, according to the purpose of the apparatus can be written:

$$
E_{2 a}=\left(E_{2 a}\right)_{F}+\left(E_{2 a}\right)_{P}
$$

where $\left(E_{2 a}\right)_{F}-$ the exergy of the wet air at $t_{2 a}, x_{2 a}, m_{l a}$; $\left(E_{2 a}\right)_{P}$ - the exergy of water vapor at $t_{2 a}, x_{2 a}$ with mass flow $G_{e v}$.

This separation of exergy air at the outlet allows obtaining:

$$
\begin{aligned}
& E_{F}=E_{1 a}-\left(E_{2 a}\right)_{F} \\
& E_{p}=\left(E_{2 a}\right)_{F}-E_{w}
\end{aligned}
$$

and exergic efficiency takes the form of

$$
\varepsilon_{e x}=\frac{E_{P}}{E_{F}}=\frac{\left(E_{2 a}\right)_{F}-E_{w}}{E_{1 a}-\left(E_{2 a}\right)_{F}}
$$

Considering moist air as a mixture of ideal gases, we obtain:

$$
\begin{aligned}
& E_{1 a}-\left(E_{2 a}\right)_{F}=m_{d . a} \cdot\left(1+x_{1 a}\right) \times \\
& \times\left[c_{p, w . a}\left(t_{1 a}-t_{2 a}\right)-T_{e}\left(c_{p, w . a} \cdot \ln \frac{T_{1 a}}{T_{2 a}}-R_{w . a} \cdot \ln \frac{P_{1 a}}{P_{2 a}}\right]\right.
\end{aligned}
$$

where $m_{d . a} \cdot\left(1+x_{1 a}\right)$ - mass flow of moist air; $c_{p, w . a}-$ the isobar heat capacity of the wet air in the temperature range $t_{l a}, t_{2 a} ; R_{w . a}$ - the gas became wet air; $P_{l a}, P_{2 a}-$ air pressure at the entrance and exit of the apparatus.

The calculated equations for $c_{p, w . a}, R_{w \cdot a}, P_{2 a}$ are given in the next section.

For the exergy stream of water vapor and water, use the equation for real gases:

$$
\begin{gathered}
\left(E_{2 a}\right)_{P}=G_{e v}\left[\left(\left(h_{2 a}\right)_{P}-h_{e}\right)-T_{e}\left(\left(\mathrm{~S}_{2 a}\right)_{P}-S_{e}\right)\right] \\
\left(E_{2 a}\right)_{P}=G_{e v}\left[\left(h_{w}-h_{e}\right)-T_{e}\left(\mathrm{~S}_{w}-S_{e}\right)\right]
\end{gathered}
$$

where $h_{w},\left(h_{2 a}\right)_{P}$ - the enthalpy of water and water vapor at the appropriate temperatures $t_{w}, t_{2 a}$.

When taking environmental parameters $T_{e}=273 \mathrm{~K}$ and $P_{e}=100 \mathrm{kPa}$, the values of $h_{e}, S_{e}$ for water are zero and the exergy of the product stream is written as follows:

$$
\begin{aligned}
& \left(E_{2 a}\right)_{P}-E_{w}=m_{d \cdot a} \cdot\left(x_{2 a}-x_{1 a}\right) \times \\
& \times\left[\left(\left(h_{2 a}\right)_{P}-h_{w}\right)-T_{e}\left(\left(\mathrm{~S}_{2 a}\right)_{P}+S_{w}\right)\right]
\end{aligned}
$$

After substituting (15) and (12) in (11) it can be obtained the following dependence:

$$
\varepsilon_{e x}=\frac{\left(x_{2 a}-x_{1 a}\right) \cdot\left[\left(\left(h_{2 a}\right)_{P}-h_{w}\right)-T_{e}\left(\left(\mathrm{~S}_{2 a}\right)_{P}+S_{w}\right)\right]}{\left(1+x_{1 a}\right) \cdot\left[c_{p, w \cdot a}\left(t_{1 a}-t_{2 a}\right)-T_{e}\left(c_{p, w \cdot a} \cdot \ln \frac{T_{1 a}}{T_{2 a}}-R_{w \cdot a} \cdot \ln \frac{P_{1 a}}{P_{2 a}}\right]\right.}
$$

\section{Results}

Based on the results of calculations, graphic dependencies were constructed, Figures 3, 4 for both types of constructive execution.

Based on the calculations in Figure 3 the dependence of the specific wet current on the relative humidity is presented. It can be seen that with an increase in relative humidity, the specific moisture influx decreases.

Based on the calculations in Figure 4, the dependence of the exergent efficiency on the relative humidity is presented. It can be seen that when the relative humidity increases, the exergic efficiency decreases. 


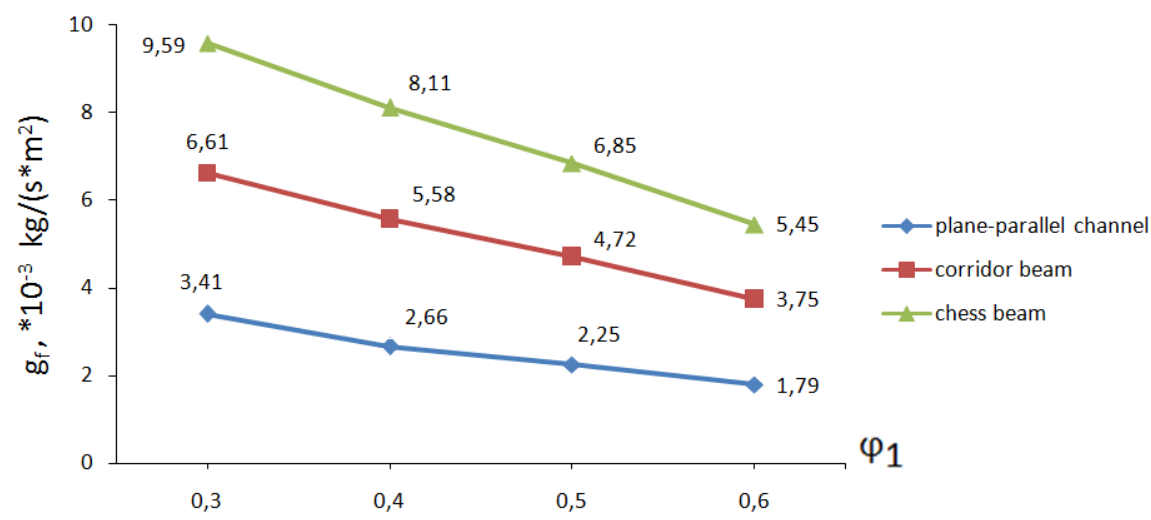

Figure 3 - The dependence of specific wet current on relative humidity

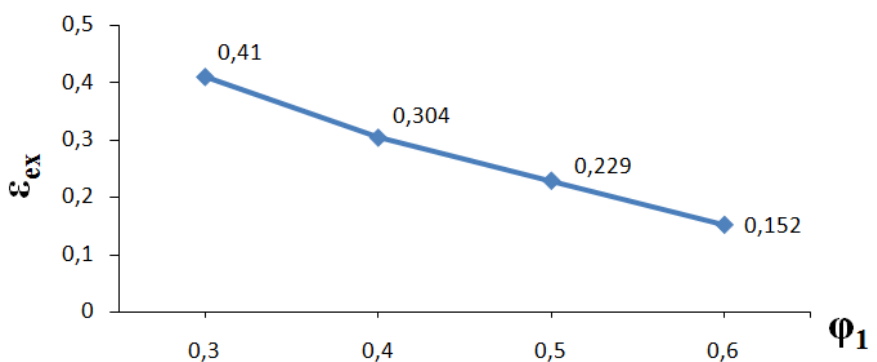

Figure 4 - The dependence of exergic efficiency on relative humidity

\section{Conclusions}

As a result, the thermophysical and design model of evaporative cooling of air in air-cooled contact type with capillary-porous structures was developed. The following dependencies are calculated:

- water consumption per unit of heat exchange surface;

- the effect of relative humidity on exergic efficiency.
This method of cooling air is characterized by the following advantages:

- the lowest water consumption per unit of heat exchange surface compared with other methods (e. g. spray nozzles);

- zero discharge of drip liquid, which does not require further separation.

Finally, the estimation of energy efficiency of the air vent is proposed on the basis of the exergent method of thermodynamic analysis.

\section{References}

1. Gorin, A. N., \& Doroshenko, A. V. (2007). Alternative Refrigeration Systems and Air Conditioning Systems, Nordpress, Donetsk, Ukraine.

2. Velasso, E., Rey F. I., Tejero A., \& Flores F. E. (2009). Performance of three different evaporative cooling systems. Proceedings of the 7th World Conference on Experimental Heat Transfer, Fluid Mechanics and Thermo-dynamics.

3. Cheban, D. N., \& Doroshenko A. V. (2013). Use of porous ceramics in the field of evaporative cooling and theoretical analysis of combined systems. Refrigeration Technique and Technology, No 2(142), pp. 4-10.

4. Arseniev, V. M., Miroshnichenko V. V., \& Borisov N. A. (2015). Exergy efficiency of technogenic cooling of cyclic air of a gas turbine plant, Refrigeration Technique and Technology, Vol. 51, Issue 6, pp. 6-11.

5. Isachenko, V. P., Osipova, V. A., \& Sukomel, A. S. (1969). Heat Transfer. Energy, Moscow, Russia.

6. Bykov, A. V. (1980). Thermophysical Bases for Artificial Cold Production. Food industry, Moscow, Russia.

7. Chumak, I. G., Laryanovsky, S. Yu., et al. (2006). Cooling Installations. Palmyra, Odessa, Ukraine.

8. Tsatsaronis, D. (2002). Interaction of thermodynamics and economics to minimize the cost of the energy-converting system. $\mathrm{Ne}-$ gotiant, Odessa.

9. Morozyuk, T. V. (2006). The theory of refrigerating machines and heat pumps. Negociant, Odessa, Ukraine.

10. Arseniev, V. M. (2012). Heat Pump Energy Conservation Technology. Sumy State University, Sumy, Ukraine.

11. Gerasimov, N. A., \& Kurilev, E. C. (1970). Cooling Installations. Mechanical Engineering, Saint Petersburg, Russia.

12. Pavlov, K. F., Romankov, P. G., \& Noskov, A. A. (1964). Examples and tasks on the course of processes and apparatuses of chemical technology. Chemistry, Moscow, Russia.

13. Stefanov, E. V. (2005). Ventilation and Air Conditioning. AVOK North-West, Saint Petersburg, Russia. 
14. Lipa, A. I. (2010). Air conditioning. The basics of the theory. Modern air treatment technology. VMV Publishing House, Odessa, Ukraine.

15. Zhuk, K. B., \& Doroshenko, A. V. (2012). Prospects of use of capillary - porous structures in evaporative coolers of gases and liquids. Sustainable development and artificial cold. Proceedings of the 8th International Scientific and Technical Conference, pp. 510-513.

16. Cheban, A. N., \& Doroshenko, A. V. (2012). Use of porous ceramics in the field of evaporative cooling. Sustainable development and artificial cold. Sustainable development and artificial cold. Proceedings of the 8th International Scientific and Technical Conference, pp. 174-177.

17. Doroshenko, A. (1992). Compact heat and mass exchange equipment for refrigeration equipment (theory, calculation, engineering practice). Doctoral Thesis, Odessa Institute of Low-Temperature Technology and Energy, Odessa, Ukraine.

\title{
Числове моделювання випарного повітроохолоджувача 3 капілярно-пористою структурою
}

\author{
Арсеньєв В. М., Шулумей А. В. \\ Сумський державний університет, вул. Римського-Корсакова, 2, 40007, м. Суми, Україна
}

\begin{abstract}
Анотація. Застосування випарного охолодження повітря в різних технологіях дозволяє знизити енерговитрати i поліпшити екологічні показники. Зважаючи на перспективність використання повітроохолоджувачів 3 капілярно-пористою структурою, розроблена математична модель робочого процесу для апаратів контактного тепломасообміну. У результаті розроблена термофізична модель випарного повітряного охолоджування із застосуванням капілярно-пористих структур. Запропонована модель ураховує завершеність процесу з температурною ефективністю 0,6-0,7 при постійній температурі води на рівні температури мокрого термометра. Запропоновано спосіб оцінювання енергоефективності повітроохолоджувача на основі ексергетичного методу термодинамічного аналізу. Наведений спосіб охолодження повітря характеризується такими перевагами як найнижча витрата води на одиницю поверхні теплопередачі, а також нульові витоки краплинної рідини, що не потребує подальшого розділення. У результаті запропоновано спосіб оцінювання енергоефективності запропонованої конструкції на основі ексергетичного методу термодинамічного аналізу.
\end{abstract}

Ключові слова: випарне охолодження, капілярно-пориста структура, теплофізичне моделювання, ексергетична ефективність. 